Case Report

\title{
Laparoscopic Transperitoneal Approach for Vesicovaginal Fistula Repair: the First Experience
}

\section{Terapi Pembedahan Fistula Vesikovagina secara Laparoskopik Transperitoneal: Pengalaman Pertama}

\author{
Jumadi Santoso, Sawkar V Pramod \\ Department of Urogynecology \\ Faculty of Medicine University of Padjadjaran/ \\ Dr. Hasan Sadikin Hospital \\ Bandung
}

\begin{abstract}
Objective: To report our first experience in transperitoneal laparoscopic repair of vesicovaginal fistula in Dr. Hasan Sadikin Hospital.

Method: A 31-year-old female presented with vesicovaginal fistula after cesarean section. Patient complained of urinary incontinence since 5 years ago. After a failed trial of conservative treatment with catheter drainage, a transperitoneal laparoscopic repair was performed. Initially, cystoscopy was performed to confirm the fistula location and for bilateral ureteric catheterization. A 4-port technique was performed with the patient in lithotomy position and slightly Trendelenburg. Without opening the bladder, the fistula tract was excised and the bladder was separated from the anterior vaginal wall. Both the bladder and vaginal walls were then closed separately using intracorporeal suturing, interposed with the omentum.

Result: Total operative time was $\mathbf{2 7 0}$ minutes. Normal diet was resumed on day 1, drain was removed on the first day after surgery, and the patient was discharged on the second day with an indwelling catheter. Surgical wound showed good cosmetic result and no leakage was identified from cystogram after 2 weeks. The catheter was removed after 2 weeks.

Conclusion: Laparoscopic transperitoneal repair of vesicovaginal fistula with omentum inteposition is feasible in Dr. Hasan Sadikin Hospital with good outcome, short hospital stay, and good cosmetic result.

[Indones J Obstet Gynecol 2014; 4: 223-225]
\end{abstract}

Keywords: laparoscopy, vesicovaginal fistula

\begin{abstract}
Abstrak
Tujuan: Untuk melaporkan pengalaman pertama kami dalam melakukan terapi pembedahan fistula vesikovaginal secara laparoskopik transperitoneal di RS Dr. Hasan Sadikin.

Metode: Seorang perempuan 31 tahun, dengan diagnosa fistula vesikovaginal setelah operasi seksio sesarea. Keluhan BAK mengompol dirasakan sejak 5 tahun yang lalu. Setelah terapi konservatif dengan pemasangan kateter gagal, dilakukan terapi pembedahan laparoskopik transperitoneal. Tahapan pertama dalam terapi pembedahan tersebut adalah tindakan sistoskopi yang dilakukan untuk menentukan lokasi fistula dan untuk insersi kateter ureter pada kedua ureter. Laparoskopi dilakukan dengan cara transperitoneal menggunakan 4 port, dengan posisi pasien lithotomi dengan sedikit posisi Trendelenburg. Operasi dilakukan tanpa membuka buli-buli, kemudian jalur fistula dieksisi dan dipisahkan antara buli-buli dengan dinding anterior vagina. Lubang fistula pada buli-buli dan vagina masing-masing ditutup dengan jahitan, dan diinterposisi dengan omentum.

Hasil: Total waktu operasi adalah 270 menit. Pasien sudah dapat makan normal pascaoperasi hari pertama, drain dilepas hari pertama pascaoperasi dan pasien dipulangkan pada hari kedua dengan terpasang kateter urin. Hasil luka operasi sangat baik secara kosmetik dan tidak ditemukan kebocoran pada pemeriksaan sistografi pada 14 hari pascaoperasi. Kateter urin dilepas setelah 2 minggu.

Kesimpulan: Terapi pembedahan secara laparoskopik transperitoneal dan interposisi omentum pada kasus fistula vesikovaginal sangat mungkin dilakukan di RS Dr. Hasan Sadikin, dengan luaran yang cukup baik, waktu perawatan yang singkat, dan luka operasi yang baik secara kosmetik.
\end{abstract}

[Maj Obstet Ginekol Indones 2014; 4: 223-225]

Kata kunci: fistula vesikovagina, laparoskopi

Correspondence: Jumadi Santoso; Sawkar V Pramod. Department of Obstetrics and Gynecology. Faculty of Medicine University of Padjadjaran, Bandung. Telephone: 0811-2402002; 0811-248069. Email: jumadi82@gmail.com; doktervj@yahoo.co.id

\section{INTRODUCTION}

Vesicovaginal fistula (VVF) in developed countries is a surgical complication associated with gynecologic procedures. Transperitoneal hysterectomy has been shown to be the most common cause, with VVF occurring in approximately one in every 1800 hysterectomies. ${ }^{1}$ The incidence of fistula caused by any surgical procedure was estimated to be between $0.1 \%$ and $2 \%$, in which almost $70 \%$ is caused by hysterectomy. The remaining cases are caused by radiation, malignancy and infection. ${ }^{1-3}$

Several techniques exist for the repair of VVF. Vaginal repair offers the least morbidity but can be challenging for posterior fistulas. From experienced centers, success rates of $88 \%-100 \%$ have been reported in selected patients. ${ }^{4}$ Transperitoneal ap- 
proach offers excellent results but with increased morbidity. ${ }^{4-6}$ We report our first experience in laparoscopic repair for VVF following cesarean procedure.

\section{CASE REPORT}

A 31-year-old woman with history of cesarean section 5 years ago. She complained of continous urinary leakage from the vagina, without micturition sensation. After failure of 6 weeks conservative management, she was offered to undergo surgical management. Previously, she refused surgical therapy for 5 years because of financial reasons. After performing cystography, we found a vesico-vaginal fistula (Figure 1-a), with the neck of the fistula located on the posterior wall of the bladder. We performed laparoscopic repair with transperitoneal apporach. The duration of the procedure was 270 minutes. Length of hospital stay was 2 days, drain was removed on day 1 post-operative and average VAS score was 2. Patient was discharged with an indwelling urethral catheter. Post-operative cystogram was done after 14 days post-operative. We found no contrast leakage and immediately removed the urethra catheter. Patient was satisfied with good cosmetic result of the operative wound and no urinary leakage.

\section{OPERATIVE TECHNIQUE}

The patient was placed in low lithotomy position (Figure 1-b). Cystoscopy shows the supratrigonal fistula (Figure 2-1) and both ureters were catheterized using no. $5 \mathrm{Ch}$ ureteral catheter. This facilitates ureteral identification and protection during excision and closure of the fistula. A pair of long forceps was introduced to the vaginal opening and the forceps entered the fistula from vaginal side under cystoscopy. Ureteral catheter was inserted into the fistula and pulled out of the vagina using this forceps. This ureter catheter was used as a marker for fistula site (Figure 2-2). A moist surgical gauze pad was placed in the vagina to prevent leakage of gas from the abdomen and to give more traction during the laparoscopic procedure. The patient was then placed in slight Trendelenburg position. After achieving pneumoperitoneum, 4 ports were placed. We used 4 laparoscopic ports, $10 \mathrm{~mm}$ port for laparoscopic $30^{\circ}$ camera, three $5 \mathrm{~mm}$ ports was used for the operator and assistance (Figure 1-c).

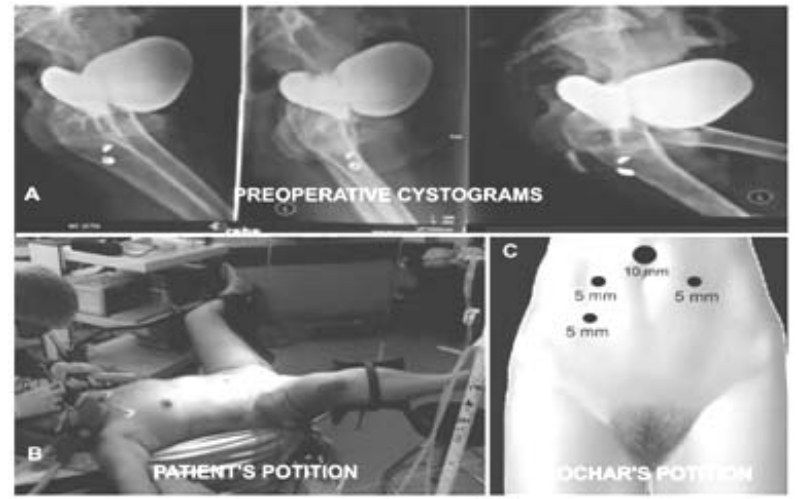

Figure 1. Preoperative Cystograms (a), patient (b) and trochar (c) positions

The first step was dissection of the uterus. We found some mild uterus adhesion to the adjacent omentum (Figure 2-3). The next step was dissection of the vesicovaginal space. Dissection was made until we identified the ureteral catheter that was previously inserted into the fistula (Figures 2-4 and 2-5). The fistulous tract was sharply excised, creating a lateral margin of viable tissue wide enough to allow subsequent closure (Figure 2-6). After excision of the tract, meticulous dissection was performed to separate the bladder from the vagina using gentle countertraction and laparoscopic scissors. Vaginal closure was done in single layer with interrupted 2-0 absorbable sutures (Figure 2-7). The bladder was closed using 2-0 long absorbable suture in two layers of running suture with perpendicular direction from vaginal closure (Figure 2-8). The omental interpositional flap was advanced over the vaginal closure and sutured to the anterior vaginal wall, distal to the vaginal closure (Figure 2-9). The bladder was irrigated with saline to ensure watertight closure. A silicone drain no 0.4 was placed. Bladder drainage was accomplished with an $18 \mathrm{~F}$ indwelling catheter. No suprapubic cystostomy was used.

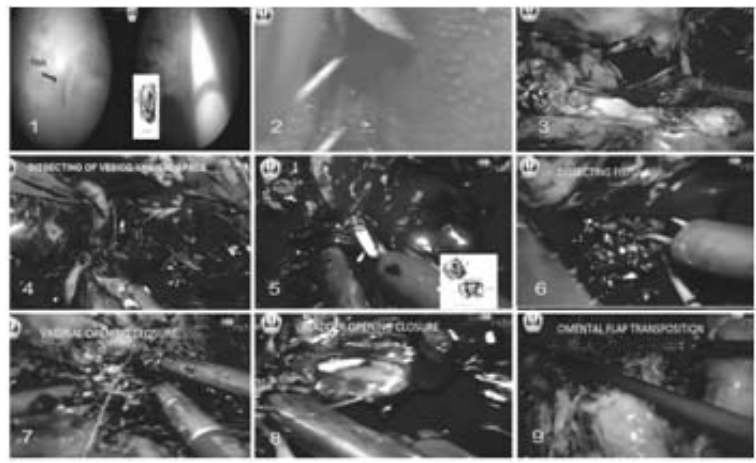

Figure 2. The steps of Operations. 
The total operative time was 270 minutes, with an estimated blood loss of $50 \mathrm{ml}$. The patient was discharged on the second post-operative day, with an average VAS score of 2 . The urethral catheter was removed at 2 weeks after it was confirmed there was no contrast leakage under cystogram (Figure 3-a). The patient was asymptomatic with normal urination at 3-months follow-up with good cosmetic outcome of the surgical wound (Figure 3b).

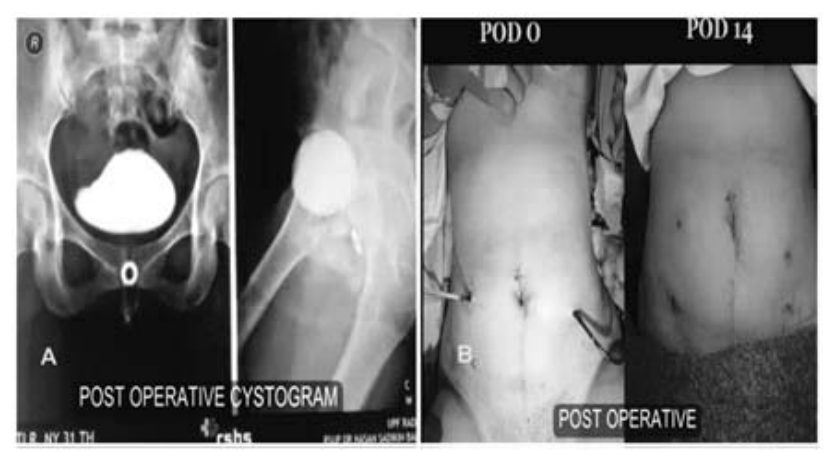

Figure 3. Postoperative results.

\section{DISCUSSION}

VVF is an uncommon complication with a reported incidence of 0.1\%-0.2\% after hysterectomy. Fistulas may be successfully repaired with a transperitoneal, vaginal or combined approach. The choice of approach usually depends on the surgeon's preference and experience. ${ }^{4}$ The number and complexity of surgical cases performed with laparoscopic repair is ever-growing and is currently becoming an alternative to laparotomy for many procedures. The advantages of a minimally-invasive procedure are well known, including magnification during the procedure, better hemostasis, decreased pain and shorter hospital stay with a more rapid recovery and earlier return to daily activities. 1,4

This is our first experience in laparoscopic repair for vesicovaginal fistula. Transperitoneal approach has advantages such as a bigger operative field and easier insertion of interpositional flap than vaginal approach. Some literatures have also reported their experience in laparoscopic procedure for vesicovaginal fistula repair, closure rate was $87.1 \%$, with $15.6 \%$ remaining incontinent, others report a success rate of $75 \%$ and $92 \% .7,8$

The exposure and magnification afforded by laparoscopy facilitates efficient and direct access to the fistula, meticulous dissection and fistula resection. Tension-free closure of well-vascularized flaps can be done with interposition of the omental flap between the suture lines. Approximation of the bladder under magnification allows the procedure to be completed without suprapubic tube placement.

\section{CONCLUSION}

Laparoscopic VVF is a feasible and efficacious approach for VVF repair. Based on our first experience, it seems to be an excellent alternative to the traditional open surgery but it requires experience in laparoscopic pelvic surgery with intracorporeal suturing.

\section{REFERENCES}

1. Richman MB, Goldman HB. Vesicovaginal fistula: Abdominal approach. New York: Marcel Dekker; 2005.

2. Singh O, Gupta SS, Mathur RK. Urogenital fistulas in women: 5-year experience at a single center. Urol J 2010; 7: 35-9.

3. Audu BM, Kullima AA, Bako B. Epidemiology of vesico-vaginal fistula: no longer a calamity of teenagers. J Obstet Gynecol 2008; 28: 432-3.

4. Ou CS, Huang UC, Tsuang M, et al. Laparoscopic repair of vesicovaginal fistula. J Laparoendosc Adv Surg Tech A 2004; 14: 17-21.

5. Zarin M, Khan M, Afridi MR, et al. Transabdominal repair of vesicovaginal fistula: an experience of 27 cases. Pak J Med Sci 2010; 26: 581-4.

6. Modi P, Goel R, Dodia S. Laparoscopic repair of vesicovaginal fistula. Urol Int 2006; 76: 374-6.

7. Ijaiya MA, Rahman AG, Aboyeji AP, et al. Vesicovaginal fistula: a review of Nigerian experience. West African J Med 2010; 29: 293-8.

8. Sjøveian S, Vangen S, Mukwege D, et al. Surgical outcome of obstetric fistula: a retrospective analysis of 595 patients. Acta Obstet Gynecol Scand 2011; 90: 753-60. 